\title{
Multi-Dimensional Economic Voting in Spain: the 2008 Election
}

\author{
Marta Fraile \\ Institute of Public Goods and Policies (IPP) \\ Consejo Superior de Investigaciones Científicas (CSIC) \\ Madrid (Spain) \\ marta.fraile@,csic.es
}

Michael S. Lewis-Beck

Department of Political Science

University of Iowa

Iowa City, IA 52242

michael-lewis-beck@uiowa.edu

Published at Electoral Studies 32(3): 465-469 


\begin{abstract}
Economic voting studies remain contentious in Spain. The notion is widely-held that there is no economic vote in that country, due to the pervasive and effacing influences of left-right ideology. Still, a growing number of investigations show a significant impact of economic evaluation on the vote choice in Spanish national elections. At least one possible exception here is the 2008 election, where the question has received no systematic treatment. In this study, we explore the impact of economic voting in that contest. We find, first, the presence of strong economic voting of the valence kind. Second, we find that two hitherto unstudied dimensions of economic voting - position and patrimony- have their own independent effect.
\end{abstract}

\title{
Keywords:
}

Valence Economic Voting, Position Economic Voting, Patrimonial Economic Voting, Spain 2008 general elections.

\section{Highlights:}

Economic issues played a significant role in 2008 Spanish election The economy is important to Spanish voters in three ways: valence, position and patrimony.

The three dimensions in the Spanish economic vote are relevant despite the importance of ideology 
With respect to the economic voting hypothesis, the orthodoxy has been that for Spanish national elections there is none (Gunther et. al. 1986; Maravall and Przeworski, 2001). However, this orthodoxy has not gone without challenge in the literature (Fraile, 2005). Certain current research efforts, in fact, have offered statistically strong demonstrations of the presence of the economic vote in the 2000 general election in particular (via a national election survey), and more generally in the general elections held between 1982 and 2008 (via a pool of national survey) (see Fraile and Lewis-Beck 2010 and Fraile and Lewis-Beck 2012). Moreover, a new time series model, based heavily on macroeconomic indicators, served well as a forecasting tool for the 2012 contest (Magalhaes, et al. 2012). Thus, evidence in favor of the economic voting idea is accumulating for Spain. But does that mean that the economy always places itself on the voter's agenda?

The 2008 national election provides a challenge in that regard. Much published work suggests for that competition what mattered was ideological partisan polarization. That is, the orthodoxy was, if need be, reestablished, with the forces of left-right thinking coloring virtually all voter opinion, including that about the direction of the national economy. In sum, the "super-issue" that determined choice was ideology, subsuming all others, including economic evaluations. Below, we provide the substantive background on 2008 that makes the case for no economic voting. For context, we also look at actual economic conditions under Zapatero's first mandate, beginning in 2004. We observe that, at least toward the end of that mandate, economic troubles were becoming quite visible. Then we examine economic voting theory as applied to Spain, and propose testing it against 2008 data, namely the large and wellexecuted CIS national election survey. In logistic regression models, with full controls, we do find that ideology has a very strong impact on vote choice. Nevertheless, 
economic evaluations of the national economy still manage strong effects in their own right. Moreover, we show, for the first time, that these effects unfold along multiple dimensions, including position and patrimony, as well as the traditional valence model of economic voting.

\section{Political Background: The 2008 Spanish general elections}

The tenth general election in contemporary Spain saw the Spanish Socialists (PSOE) attain their second consecutive win under the leadership of Zapatero. This election arrived after a first mandate, where the main opposition party (the conservative Partido Popular, the PP) had adopted a strategy of very aggressive opposition, polarizing public opinion on most fronts. Moreover, the 2004-8 Socialist mandate can be characterized as one in which political issues were largely positional (with opinions arrayed along a continuum) rather than valence (with opinion at one main value).

Overall, the majority of the legislative initiatives were intensively contested by the PP. Controversial topics included the revision of the Spanish Territorial model and ETA terrorism. Also, there were a number of highly laws, namely legislation to make divorce easier, an historical memory law on the Spanish Civil War and Franco's dictatorship, legalization of same-sex marriage, educational system reform that removes religion as an obligatory course and requires instead a civics course. All these topics can be considered as positional, with public opinion on them widely spread. As a consequence, some have held the 2004-8 Socialist mandate to be the most divisive legislature in new Spain's 31 years of democracy (Field, 2009). Other published scholarship on these issues of 2008 have appeared, but not have addressed the question of the role played by the economy. (See in particular the excellent collection on the 2008 elections, by Montero and Lago 2010, which does not contain a chapter on economic voting). This neglect may be understandable given the special circumstances 
of ideological-partisan polarization throughout the term. Still, in light of the evidence emerging from other elections, it seems worth examining what, if anything, the economy can add to the story of the 2008 ballot box.

\section{Economic Background: The 2008 Spanish General Elections}

When the Socialists won the 2004 election the Spanish economy was having one of the most successful economic periods of its modern history, highlighted by the country's unexpected accession to the European Monetary Union as a founding member. Moreover, between 1996 and 2007, the Spanish economy experienced average annual economic growth rates of around three per cent. This growth was based largely on the high levels of consumption driven by low interest rates, increasing family debt, and lower levels of public debt (Royo, 2009, 437). Only in the last two years of its first term did the Socialist administration focus more on supply-oriented measures. The 2006 and 2007 budgets increased spending in areas such as education, research and development, and infrastructure. Table 1 provides a summary of the main objective economic indicators during the first Zapatero's mandate. Obviously, under that incumbent socialist government the economy performed well, until worrisome signs begin to appear in the last year (2008).

\section{[TABLE 1 ABOUT HERE]}

As an issue, then, the economy began to garner negative attention before the forthcoming electoral campaign, when economic indicators started to signal an international financial crisis. From that moment, the PP centered its electoral campaign on the economic issue. First, at the start of the campaign it chosen as the party's economic spokesperson Pizarro, a well-known businessman (and ex-President of the 
Spanish electricity company Endesa). For example, it promoted a television debate between Pizarro and Solbes, the current Minister of Economy and Finance. In short, the economic issue, in its classic valence sense, began to clearly enter the picture, with the main opposition party making it the centerpiece of its campaign.

Indeed, the last months of this Socialist mandate showed the tip of the iceberg that has been the worst financial crisis since the Great Depression of the 1930's. Generally, negative perceptions about the current economic situation and pessimistic economic future expectations greatly increased in Europe during the period. For example, the percentage of the European public predicting a worsening national economic situation in the next twelve months rose from $30 \%$ in 2007 , to $60 \%$ at the beginning of 2009 (Eurobarometers 67.2, 68.1, 69.2, 71.1, 71.2 and 71.3). The Spanish public opinion was not an exception (see Figure 1 below). By the end of the Socialist mandate around $40 \%$ of those interviewed declared the present economic situation to be "bad" or "very bad," and 35\% declared that the situation will be even "worse" in the coming months. (Compare these percentages to the values 10\%-15\%, scores registered at the mandate's beginning, in 2004).

\section{[FIGURE 1 ABOUT HERE]}

Did public perceptions of the economy reflect the economic reality? Figure 2 suggests that they did. It shows the evolution across the whole mandate of the pessimistic economic expectations (that is, the percentage of interviewed declaring that the economic situation of the country would be worst in the coming months) and of the negative views about the present economic situation of the country (that is, the percentage of interviewed declaring that the present economic situation of the country is bad or very bad). As can be seen, there is a clear trend of increasing pessimism and 
negative views about the economy. Pessimism becomes more evident as the date of the elections approached, exactly the period in which the economic performance becomes poorer.

\section{Economic Voting Theory and the Spanish Case}

In past election survey efforts, classic economic voting effects, of a valence nature, have been found (González, 2002; Lancaster and Lewis-Beck, 1986; Fraile and Lewis-Beck, 2010; Fraile and Lewis-Beck, 2012, forthcoming). In particular, the Spanish voter appears to punish or reward the incumbent, according to whether economic times are bad or good. That is to say, they make generally evaluations that are retrospective (assessing past economic performance) and sociotropic (assessing the entire economy), before casting their economic vote. However, none of the evidence cited for this conclusion looks specifically at the 2008 election. Therefore our first order of business is to test for valence economic voting in that contest.

Second, following recent theoretical developments within economic voting theory (Lewis-Beck and Nadeau, 2011; Lewis-Beck, Nadeau and Foucault, 2013; Nadeau, Foucault and Lewis-Beck, 2010), we explore two other dimensions of economic voting: position and patrimony. As noted, positional economic voting considers different positions on economic policy, such as taxation, regulation, state intervention. For example, what is the electoral effect of favoring more government regulation of business? While this policy dimension of economic voting has long been noted (Kiewiet, 1983), only recently has much work been done on it. Patrimony refers to the amount of material assets - wealth - the voter owns. This sort of economic voting is relatively new, both in terms of theory and evidence. 
We suggest that these two dimensions might be specially apropos in the 2008 Spanish General elections for different reasons. During the first Zapatero legislature many divisive positional issues, related to morality and religion were at the political fore front politics, as noted above. These policies generated heated opposition from the conservative PP party, the Catholic Church, and the conservative civil society organizations. A consequence was political and social conflict both in the Parliament and in the streets. Given such intensively polarized public opinion, the positional dimension of the economy might be of particular relevance. Influenced by the general polarized climate, electors could naturally extend their polarized views to certain economic policy issues.

What of the influence of patrimony? The general finding elsewhere has been that voters with more patrimony tend to support parties on the right, even after the usual controls on party or ideology. Such a pattern could well be operating among the 2008 election, given the increasingly pessimistic economic circumstances voters were facing. We argue that voters with a greater accumulation of wealth (houses, land, other buildings, stocks, etc.) will especially fear the coming economic crisis. Therefore, they turn throw support to the main opposition party, the conservatives, since they tend to defend free market and free enterprise over social policies and higher taxes.

\section{Data and Estimation}

We use the 2008 General Election Panel Survey, conducted by CIS and composing a national probability sample, taking place in two waves. In the first wave (CIS2750), face-to-face interviews were carried out between January 21 to February 4 one month before the general election, with $\mathrm{N}=18,625$ adults, randomly sampled (within strata of the Spanish regions). The second wave (CIS2757) was a random 
sample from the first wave sample, constituting a representative national sample. The interviews took place after the general election, from March 12 to May 12, and were again face-to-face, for a total $\mathrm{N}=6855$ (interviewed in both waves). Here we utilize the sample interviewed in both waves, dubbing the first the pre-election wave, and the second the post-election wave. To estimate our models, we employ binomial logistic regression, including prediction of the chances of voting for the Incumbent (PSOE) versus the main Opposition party (the PP). The variables used, and their operationalization, appear at the bottom of Table 2

\section{The Model and the Statistical Results}

To carry out our tests, we embed our economic variables in a well-controlled specification of the vote (incumbent v. opposition) in Spanish general elections. With respect to general theory, this vote choice can be explained as a political behavior determined by short-term and long-term forces, as follows:

Vote $=\mathrm{f}($ Socio-Demographics, Left-Right Ideology, Economic Issues) Eq.1. The operationalization of the items measuring each conceptual variable appears at the bottom of Table 2. We observe, first, that the model does a rather good job of accounting for variation in the vote, with a Pseudo-R-squared of .46 (column 5, Table 2). Further, we observe the expected effects of social class, income, gender and religiosity. Of special interest is the effect of ideology. Clearly, it has powerful effects. The Spanish voters' identification with the left or the right acts decisively on their vote choice, as the single most important predictor of party preference.

[TABLE 2 ABOUT HERE] 
Our particular question, however, regards economic voting, and whether it manages any independent effect, after the potent control on ideology. We report that, even in the most fully controlled model (column 5, Table 2), it easily exerts a statistically significant impact at well beyond the .001 level. Thus, ideology, powerful as it is, does not erase the influence of the economy on the voter. Let us explore that influence in more detail. First, with respect to valence politics, voters who perceive that the national economy has performed well (badly) are more likely to vote for (against) the government, as the significant coefficient shows. Further, this affect remains fairly stable across the different specifications (columns 1-5), within a narrow range of 4.1 to 4.9. An implication of these steady values is that valence economic voting stands orthogonal to it other dimensions, to which we now turn.

For positional economic voting, the negative sign on the coefficients means those against paying higher taxes are less likely to vote Socialist. This makes theoretical sense, saying those wanting lower tax burden to support social services, tend to be more conservative, quite apart from their general feelings about the country's economic performance as a whole. With respect to patrimony, our particular measure scores itself along an ownership scale - nothing, one house, two houses, land or other property. We observe that as ownership increases, the voter is less likely to favor the Socialists. This finding is in line with findings elsewhere (Lewis-Beck and Nadeau, 2011; Lewis-Beck, Nadeau and Foucault, 2013; Nadeau, Foucault and Lewis-Beck , 2010) and within Spain persists with its own influence, independent of valence or positional economic attitudes.

In sum, all three dimensions of economic voting have significant effects, independent of each other. Further, because they all follow the same metric (0-1), we can see that the 
valence dimension dominates, with a score of 4.14 , compared to 1.04 for patrimony, and .53 for position.

We can also look at effects in terms of a shift in probably of voting for the incumbent, as the values on the independent variables go from minimum to maximum. After set all the other $\mathrm{X}$ values at their mean, the predicted incumbent probability changes as follows (when the economic variable in question changes from its minimum to its maximum value): valence $=.33$ to $.96=63$ points difference; position $=.77$ to .65 $=-12$ points difference; patrimony $=.80$ to $.58=-.22$ difference. Again we see that valence economics has the dominant effect, followed by patrimony then position. How do these effects compare to changes in ideology? Carrying out the same exercise with ideology, moving it from minimum (extreme left) to maximum (extreme right), yields the following: $.99-.01=98$ points difference. We see, then, that ideology does have a greater impact than the economy, as expect. However, when the pure valence effects are compared to the ideology effect, we see that the former is a respectable rival, i.e., 63 points v. 98 points. Valence economics is clearly no lightweight in its influence, at least with respect to the 2008 contest.

\section{Conclusion}

A long standing view has been that the economic voting idea lacks relevance for Spain, especially because of the enduring power of left-right ideological attitudes. While this view has been repeatedly challenged in various quantitative studies of Spanish electoral behavior, it continues to be widely held. The 2008 election represents an outstanding case in point. The published literature on that contest virtually ignores the possible influence of the economic issue, focusing instead on clearly contentious 
issues of morality and religion. Here we take a first systematic look at the impact of economic evaluation on incumbent support in that election.

A principal finding is that economic issues played a significant role in 2008 vote choice, especially valence economics. That is, when voters saw the economy as performing well (badly) they tended to vote for (against) the Socialist incumbent, even in the face of strong controls on socio-demographic and ideological forces. The impact of valence considerations, in themselves, come in a respectable second place, when compared to the impact of ideology. This result gives added support to a general theory of valence economic voting in Spain.

Besides valence we uncover, for the first time, influence from two other economic dimensions - position and patrimony. Voters take positions on economic issues of the day, e.g., taxes, and that makes a difference in their vote. Also the amount they own - their patrimony - makes a difference. The significant place of these new dimensions in the Spanish economic vote merits further development in subsequent surveys. 
Table 1. Objective economic indicators in Spain (2004-8)

\begin{tabular}{lllcc}
\hline Years & $\begin{array}{l}\text { Annual Growth } \\
\text { (\% change) }\end{array}$ & Inflation rate & $\begin{array}{l}\text { Unemployment } \\
\text { rate }\end{array}$ & $\begin{array}{l}\text { Current } \\
\text { account } \\
\text { balance }\end{array}$ \\
\hline 2004 & 3.3 & 3.1 & 11 & -5.3 \\
2005 & 3.6 & 3.4 & 9.2 & -7.4 \\
2006 & 3.9 & 3.6 & 8.5 & -8.9 \\
2007 & 3.7 & 2.8 & 8.3 & -10.1 \\
2008 & 1.2 & 4.1 & 11.3 & -9.6 \\
\hline
\end{tabular}

Source: International Monetary Fund, World Economic Outlook Database, April 2009.

Figure 1. Subjective Views about the Economy. Spain 2004-2008

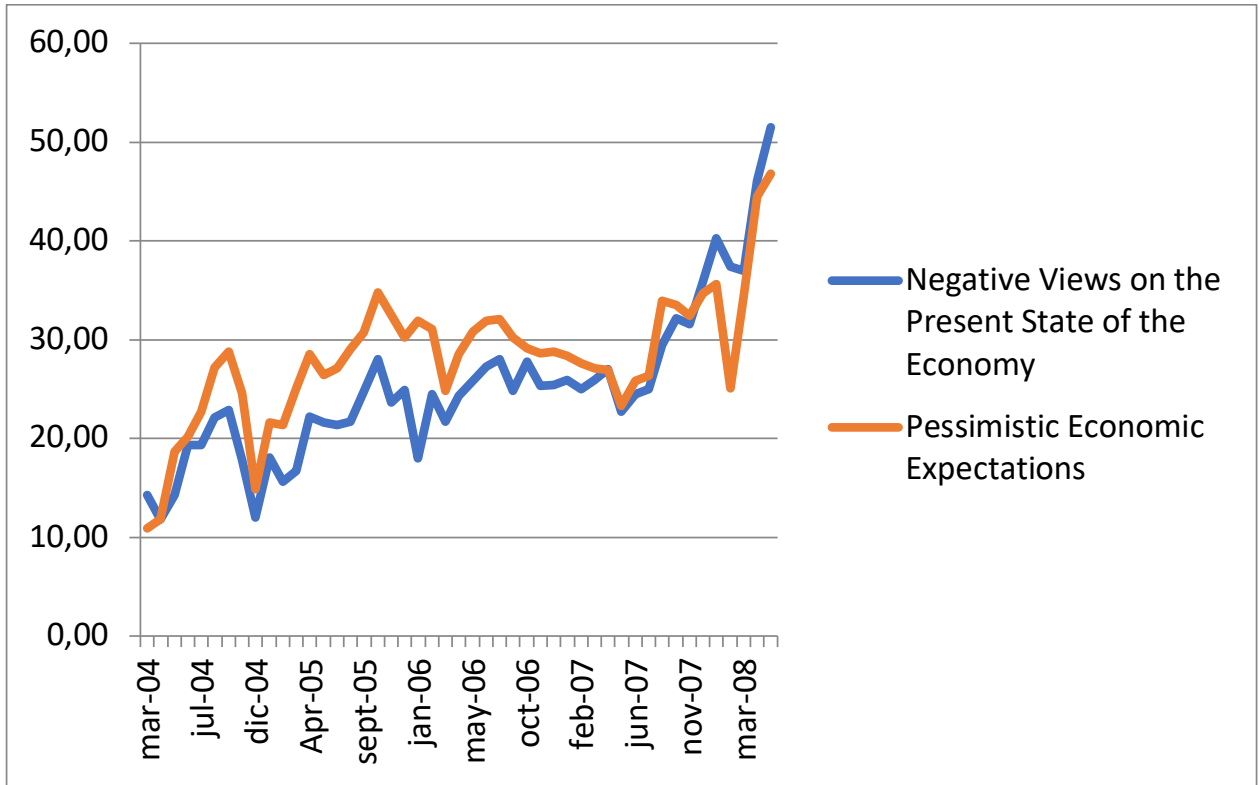

Source: Our elaboration from Centro de Investigaciones Sociológicas, Indicadores de la situación económica (www.cis.es)

Table 2. Vote for the incumbent (PSOE) versus the main opposition party (PP)

\begin{tabular}{llllll}
\hline & 1 & 2 & 3 & 4 & 5 \\
\hline Age & $0.010^{* * *}$ & 0.004 & 0.004 & $0.006^{*}$ & 0.003 \\
Male & $(0.00)$ & $(0.00)$ & $(0.00)$ & $(0.00)$ & $(0.00)$ \\
& $-0.337 * * *$ & $-0.569 * * *$ & $-0.553^{* * * *}$ & $-0.545^{* * *}$ & $-0.442 * * *$ \\
Education & $(0.08)$ & $(0.08)$ & $(0.09)$ & $(0.09)$ & $(0.10)$ \\
& -0.115 & -0.357 & $-0.405^{*}$ & -0.363 & -0.342 \\
& $(0.17)$ & $(0.19)$ & $(0.20)$ & $(0.20)$ & $(0.24)$
\end{tabular}


Religiosity

$\begin{array}{lllll}-2.478 * * * & -2.522 * * * & -2.482 * * * & -2.471 * * * & -1.405 * * *\end{array}$
$(0.16)$
$(0.17)$
$(0.18)$
$(0.18)$
$(0.23)$

Social class:

New middle class

0.121

0.175

0.188

0.173

0.193

Old middle class

(0.13)

$(0.14)$

$(0.15)$

$(0.15)$

$(0.18)$

$-0.104$

$-0.054$

0.043

0.092

0.192

$(0.14)$

$(0.16)$

$(0.16)$

$(0.17)$

Skilled manual worker

$0.391 * *$

$0.456 * *$

$0.513^{* * *}$

$0.503 * *$

$0.529 * *$

$(0.13)$

$(0.15)$

$(0.15)$

$(0.16)$

$(0.19)$

Unskilled manual worker

$0.457 * *$

$0.527 * *$

$0.579 * * *$

$0.566^{* *}$

$0.592 * *$

(0.16)

$(0.18)$

$(0.18)$

$(0.18)$

$(0.22)$

Income:

\begin{tabular}{|c|c|c|c|c|c|}
\hline Second quartile & $\begin{array}{l}-0.367 * * \\
(0.12)\end{array}$ & $\begin{array}{l}-0.465 * * * \\
(0.13)\end{array}$ & $\begin{array}{l}-0.480 * * * \\
(0.14)\end{array}$ & $\begin{array}{l}-0.432 * * \\
(0.14)\end{array}$ & $\begin{array}{l}-0.333^{*} \\
(0.16)\end{array}$ \\
\hline \multirow[t]{2}{*}{ Third quartile } & $-0.314^{*}$ & $-0.418^{*}$ & $-0.438^{*}$ & -0.328 & -0.161 \\
\hline & $(0.15)$ & $(0.17)$ & $(0.17)$ & $(0.18)$ & $(0.22)$ \\
\hline \multirow[t]{2}{*}{ Fourth quartile } & $-0.484 * *$ & $-0.629 * * *$ & $-0.630 * * *$ & $-0.479 *$ & $-0.450 *$ \\
\hline & $(0.16)$ & $(0.18)$ & $(0.19)$ & $(0.19)$ & $(0.23)$ \\
\hline \multirow[t]{2}{*}{ DK/NA } & $-0.687 * * *$ & $-0.758 * * *$ & $-0.802 * * *$ & $-0.718 * * *$ & $-0.592 * *$ \\
\hline & $(0.12)$ & $(0.13)$ & $(0.14)$ & $(0.14)$ & $(0.17)$ \\
\hline \multirow[t]{2}{*}{ Economy (Valence) } & & $4.944 * * *$ & $4.825 * * *$ & $4.885^{* * *}$ & $4.141 * * *$ \\
\hline & & $(0.21)$ & $(0.22)$ & $(0.22)$ & $(0.27)$ \\
\hline \multirow[t]{2}{*}{ Economy (Positional) } & & & $-0.781 * * *$ & $-0.814 * * *$ & $-0.534 * *$ \\
\hline & & & $(0.18)$ & $(0.18)$ & $(0.22)$ \\
\hline \multirow[t]{2}{*}{ Economy (Patrimony) } & & & & $-1.178 * * *$ & $-1.048 * * *$ \\
\hline & & & & $(0.19)$ & $(0.23)$ \\
\hline \multirow[t]{2}{*}{ Ideology } & & & & & $-11.311 * * *$ \\
\hline & & & & & $(0.49)$ \\
\hline \multirow[t]{2}{*}{ Intercept } & $1.36 * * *$ & 0.044 & 0.378 & $0.597^{*}$ & $5.307 * * *$ \\
\hline & $(0.24)$ & $(0.26)$ & $(0.29)$ & $(0.29)$ & $(0.42)$ \\
\hline Pseudo-R-sq. & 0.07 & 0.21 & 0.22 & 0.23 & 0.46 \\
\hline $\mathrm{N}$ & 3756 & 3719 & 3502 & 3448 & 3448 \\
\hline
\end{tabular}

Source: CIS2757 (post 2008 election survey)

$* \mathrm{p}<.05 ; * * \mathrm{p}<.01 ; * * * \mathrm{p}<.001$. Figures in parentheses are standard errors.

Dependent variable $=1$ Vote for the incumbent (PSOE), 0 Vote for PP.

All independent variables re-codified to go from 0 to 1 except age (in years): Ideology $=$ From 0 ( (extreme left) to 1 (extreme right); Economy (Valence) $=$ From 0 (for very bad national economic conditions) to 1 (for very good national economic conditions); Economy (Positional) = From 0 (in favor of paying more taxes) to 1 (against paying more taxes); Economy (Patrimony) $=$ From 0 (no patrimony) to 1 (three kinds of properties: first and second house plus lands or other buildings); Age $=$ in years; Male $=$ 1 (for male), 0 (for female); Education = from lowest (0) to highest (1); Religiosity = From 0 (no religion) to 1 (various days a week of church attendance); For Social Class, high class is the category of reference ; For Income, the lowest (first) quartile is the category of reference. 